
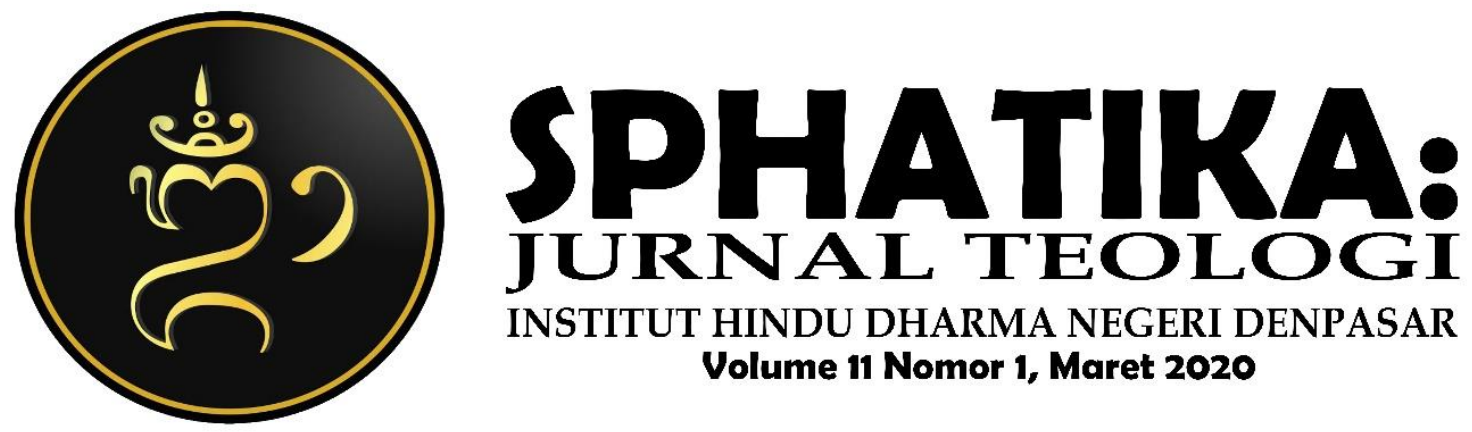

INSTITUT HINDU DHARMA NEGERI DENPASAR

Volume 11 Nomor 1, Maret 2020

\title{
NILAI FILOSOFIS TATA RUANG BANGUNAN TRADISIONAL BALI DALAM TEKS ASTA KOSALA KOSALI
}

\section{Ni Luh Komang Indah Sari}

I Made Wirahadi Kusuma

Institut Hindu Dharma Negeri Denpasar

\begin{tabular}{|ll|}
\hline Keywords: & ABSTRACT \\
\cline { 2 - 3 } $\begin{array}{l}\text { Asta Kosala Kosali, values / } \\
\text { spirituality, and building }\end{array}$ & $\begin{array}{l}\text { The concept of Balinese Architecture in the } \\
\text { arrangement of the spatial value of traditional Balinese } \\
\text { buildings which includes in the Asta Kosala Kosali text, } \\
\text { provides the spatial design and layout of the building so } \\
\text { that it has a philosophical value at the position of certain } \\
\text { buildings. Structuring the building is supported by the } \\
\text { concept of Tri Angga, Tri Mandala and lontar Asta } \\
\text { Bhumi which can be in harmony between one building } \\
\text { with another. The structure of this building can be seen } \\
\text { from the shape of Padma Bhuwana which regulates the } \\
\text { direction and symbol of the building. This can be } \\
\text { influenced by values / spirituality, conditions / potentials } \\
\text { owned, and economic commodities owned in the area that } \\
\text { will be built. }\end{array}$ \\
\hline
\end{tabular}

\section{PENDAHULUAN}

Arsitektur merupakan perwujudan kebudayaan masyarakat Hindu di Bali, sebagai acuan terhadap tercapainya keselarasan dan integrasi, baik terhadap manusia, lingkungan, maupun terhadap alam semesta. Di lain pihak, adapun faktorfaktor seperti kehidupan sosial ekonomi, sosial budaya, maupun sosial politik yang tidak kalah pentingnya dalam melandasi perwujudan arsitektur tradisional Bali. Arsitektur tradisional Bali dapat diartikan sebagai tata ruang yang mewadahi kehidupan masyarakat Bali yang telah berkembang secara turun-temurun dengan segala aturan-aturan yang diwarisi dari zaman dahulu hingga saat ini. Arsitektur 
tradisional Bali tidak terlepas dari keberadaan manuskrip Hindu serta aturan-aturan dalam merancang tata ruang bangunan Bali. Dalam dunia rancang bangun konsep globalism mengacu pada optimalisasi fungsi-fungsi indera seperti mata, telinga, kulit dan hidung. Konsep ini mengutamakan efisiensi dan produktivitas yang sejalan dengan konsep globalisasi. Untuk memenuhi kondisi-kondisi tersebut, konsekuensi bentuk-bentuk arsitektur yang fungsional, rasional, standar, lugas, memperhatikan peradaban/arsitektur lokal dan pemenuhan kebutuhan penghuni adalah alternatif dalam pengembangan desain rancang bangun sesuai dengan tuntutan kemajuan dewasa ini.

Konsep penataan tata ruang bangunan di Bali pada umumnya mengikuti aturan tata letak dan tata nilai tradisional Bali serta berlaku pada tata ruang kawasan di daerah Bali. Gelebet (1985) menegaskan bahwa aturan-aturan tradisi maupun modern sudah banyak membicarakan masalah lingkungan. Dalam alam tradisi Bali sudah dikenal adanya pengelompokkan tata guna tanah yang tercermin dalam Tri Angga (kepala, badan, kaki), tata letak bangunan seperti dalam lontar Asta Gumi dan tata ruang bangunan seperti dalam lontar Asta Kosala Kosali. Sedangkan saat ini secara modern dikenal zonning (pembagian kawasan) atau tata guna tanah/lahan. Perwujudan tata ruang bangunan tradisional di Bali sangat kompleks dan bervariasi seiring dengan perkembangan peradaban dan teknologi. Tata ruang bangunan di Bali dirancang tidak hanya untuk memenuhi tuntutan kebutuhan yang praktis, tetapi juga untuk mengekspresikan emosi atau ide-ide simbolik dan keagamaan sekuler. Pola-pola tata ruang bangunan tradisional Bali (Parwata, 2004) umumnya dipengaruhi oleh beberapa faktor, diantaranya : 1) Tata nilai/spiritualitas, umat Hindu di Bali memandang arah timur (kangin) sebagai arah yang diutamakan (sakral), 2) Kondisi dan potensi alam, dan 3) Berkaitan dengan sumber ekonomi, umat Hindu di Bali. Hal ini berhubungan erat antara pola pembangunan dengan lahan atau tanah.

Permukiman tata ruang bangunan tradisional Bali dari segi tempat tinggal masyarakat di Bali mempergunakan konsep Tri Mandala dan Tri Hita Karana yang bersumber dari lontar Asta Kosala-Kosali dan Asta Bhumi. Hal ini menciptakan keselarasan dan keharmonisan serta integrasi yang menyeluruh antara mikrokosmos 
(Bhuwana Alit) dan makrokosmos (Bhuwana Agung) berlandaskan pada tata ruang pembangunan kehidupan sosial yang religius, sebagai pandangan hidup masyarakat Hindu di Bali. Pandangan ini diwujudkan dalam seni budaya Bali, terutama pada tata ruang bangunan tradisional Bali secara kompleks dan tertata sesuai teks Asta Kosala Kosali dan Asta Bhumi.

\section{PEMBAHASAN}

\section{Tata Ruang Bangunan Tradisional Bali dalam Teks Asta Kosala Kosali}

Umat Hindu terdahulu telah memiliki konsep bangunan dengan tata ruang dan tata letak yang mengarah sudut mata angin. Tiap mendirikan sebuah bangunan di pekarangan tentunya memiliki ukuran karang yang akan dibangun. Sehingga tidak sembarangan orang dapat membangun suatu bangunan yang akan didirikannya sesuai dengan sumber sastra dan lontar Asta Bhumi, Asta Kosala Kosali dan Asta Dewata atau Astawara. Perhitungan ini perlu jarak dan waktu untuk membangun suatu bangunan yang sudah dipatokan (sikut) dengan ukuran.

Tata ruang pada bangunan tradisional Bali merupakan bagian kebudayaan yang tidak terlepas dari dinamika, budayanya dan dasar pemikiran yang sangat mendalam antara satu dengan yang lainnya sehingga saling berhubungan dan menimbulkan suatu sistem yang harmonis, bermakna serta mengandung filosofis. Secara system kemestaan menurut (Kaler 1983 dalam Suja 2010) ada tiga unsur utama dalam pembangunan yaitu wadah (badan sarira), isi yaitu prana dan jiwa atau atma yang menghidupkan badan sehingga terbentuk hubungan yang harmonis ketiga. Tata letak, termasuk berada pada tempat suci dipekarangan sebagai hulu atau kepala dan tata ruang sebagai badan/pintu masuk/angkul-angkul sebagai tapak kaki orang yang akan menempatinya. Perhitungan pada pondasi bataran/baturan dari sekian tampak ditambah dengan satu tampak ngandang (tampak kesamping) yang disebut dengan pengurip-ngurip, artinya setiap bangunan tersebut dapat hidup atau selalu memiliki jiwa atau kekuatan di dalamnya. 


\section{Struktur dan Fungsi Tata Ruang Bangunan Tradisional Bali dalam Teks Asta}

\section{Kosala Kosali}

Pada landasan struktur tata ruang memberikan penekanan pada pola keteraturan tata ruang baik secara vertikal maupun horizontal. Dalam kebudayaan Bali, satu struktur di samping mencerminkan adanya keterbukaan yang dinamis. Adapun konsep yang berkaitan dengan struktur ruang antara lain: 1) Konsep Tri Hita Karana, 2) Konsep Rwa Bhineda, 3) Konsep Tri Bhuwana dan Tri Angga, 4) Pola Tri Mandala, 5) Konsep Nawa Sanga dan Padma Bhuwana, dan 6) Konsep Dinamika.

Arah orientasi ruang dalam skala wilayah yang lebih luas dan berkeseimbangan secara keseluruhan dalam tata ruang dalam pembangunan tradisional Bali, dengan konsep arah orientasi yang berdasarkan mata angin (pengide-ider) yang bersifat universal, dan berdasarkan konsep segara-gunung yang bersifat lokal. Sumbu ritual timur-barat (Surya-Sewana) berorientasi ke arah matahari terbit dan terbenamnya matahari, pada orientasi timur tempat matahari terbit lebih utama dari barat. Sumber yang kedua adalah konsep sumbu natural spiritual KajaKelod yang dikaitkan dengan arah orientasi kepada gunung dan lautan (Nyegara Gunung, Segara-Wukir), Luan-Teben, Sekala-Niskala, Suci-Tidak Suci dan sebagainya. Segala sesuatu yang dikategorikan bersifat suci dan bernilai sakral akan menempati letak di bagian Kaja (utara) mengarah ke gunung seperti : letak pura, arah sembahyang, arah tidur dan sebagainya. Sebaiknya, segala sesuatu yang dikategorikan kurang suci dan bernilai profan, akan menempati letak bagian kelod (selatan), seperti : letak kuburan, letak kandang, tempat pembuangan sampah/kotoran,dan sebagainya bagi mereka yang tinggal di bagian Bali Selatan dan kelod berarti utara.

Perbedaan ini tidak saja terbatas pada penunjukkan arah, tetapi juga dalam beberapa aspek kehidupan. Pada bagian tengah Pulau Bali dari timur ke barat terbentang pegunungan/perbukitan dengan puncak-puncaknya antara lain: Gunung Agung, Bunung Batur, Gunung Batukaru, yang menurut konsep diatas merupakan arah orientasi sumbu natural spiritual yang utama dari aktifitas kehidupan masyarakat Bali. Manifestasi atau kekuatan-kekuatan Tuhan (siwa) dalam mata 
angin (pengider-ider) yang mengambil posisi dik widik, mendasari konsep Dewata Nawa Sanga dan konsep Eka Dasa Rudra. Konsep ini, disamping mendasari sumbu yang bersifat universal serta mendasari pola ruang Sanga Mandala. Sedangkan posisi gunung-laut, disamping mendasari sumbu linier kaja-kelod, serta mendasari pola ruang Tri Mandala. Dari dasar pola ruang Tri Mandala, dapat dijabarkan sebagai pola ruang Sanga Mandala dengan memasukkan faktor terbit matahari sebagai orientasi nilai utama sebagai pembagi masing-masing mandala dalam Tri Mandala menjadi tiga bagian. Pola Sanga Mandala pada yang lain didasarkan atas konsep PengiderIder/Dewata Nawa Sanga. Pada jenis mandala di tengah (madyaning madya) menjadi paling utama dan menjadi pusat orientasi (Subawa, 2018: 51).

Secara umum, konsep tata ruang tradisional Bali, orientasi sangat menentukan penataan zoning baik lingkungan rumah, banjar, maupun lingkungan desa. Orientasi tradisional merupakan orientasi ruang yang dibentuk oleh tiga sumbu yaitu : 1) Sumbu Religi, 2) Sumbu Bumi, dan 2) Sumbu Kosmos. Ada tiga pola tata ruang permukiman tradisional religius Bali, yaitu : 1) Pola Perempatan Agung, 2) Pola Linier, dan 3) Pola Kombinasi.

Pada pengambilan tata ruang di dalam bangunan rumah terdapat struktur dan fungsinya seperti pemilik rumah, tempat tinggal, kayangan, sanggah dan dhupa semuanya kuwu, tempat tinggal yang berada pada sudutnya disebut paduraksa. Padu artinya disambung, raksa artinya dihadang. Itu bertempat di jungut yaitu sudut. Dan yang bertempat di timur laut, Sang Singa Raksa namanya, yang berada di tenggara, Sang Aji Raksa namanya, yang berada di barat daya Sang Rudreraksa namanya, yang bertempatnya di barat laut, Sang Kalaraksa namanya. Itulah penguat pekarangan perumahan bila sudah sesuai pada sikut, sama-sama merupakan raga Bhatara buahnya, makmur yang berhubungan dengan rumah itu dan segala sesuatu tidak mahal, terutama kebahagiaan itu susut, binatang ternaknya sehat-sehat. Dan bila tidak sesuai sikut itu, sama dengan berbadan Kala Bhuta Dengen jadinya.

Orang yang berumah dipekarangan itu akan cepat meninggal dan kebahagiaan cepat menyusut. Orang yang berumah dipekarangan itu tiga keturunan akan amat panas (menderita disantap oleh Kala Bhuta Dengen. Bila sikut itu sesuai, Dewa Bhatara akan menjaga menjadi mantap pekarangannya itu. Sang Sariraksa 
menjadi Bhatari Sri, Sang Ajiraksa menjadi Bhatara Guru, Sang Kudraraksa menjadi Bhatara Rudra, Sang Kalaraksa menjadi Bhatari Uma, tangannya lentur, lembut disebut tambak (yang menghadang), semua serba murah, Tidak kekurangan pangan, dan minuman. Demikian isi sastra yang disampaikan dalam teks lontar Asta Kosala Kosali, hal 23). Di dalam teks lontar Asta Bhumi menjelaskan ada beberapa posisi/tata letak yang memiliki fungsi dalam tata ruang pembangunan tradisional Bali diantaranya : 1) Baratdaya akan mengalami keberuntungan dalam makanan, rejeki lancar, dan hewan peliharan menjadi selamat, 2) Barat, akan mengalami hasil memperoleh makanan, namun akan mengalami kesakitan, 3) Baratlaut, akan dimangsa oleh Kala dan mengalami kekurangan makanan, 4) Utara, akan terjadi kesakitan berakhir dengan kematian dan, 5) Timur laut, akan mengalami marah dan bisa bunuh diri, berakhir kematian.

\section{Makna dan Nilai Filosofis Tata Ruang Bangunan Tradisional Bali dalam Teks Asta Kosala Kosali}

Kekuatan sebuah keragaman arsitektur tradisional Bali memyebabkan terjadinya perubahan terhadap perkembangan hubungan antara manusia dengan ruang, waktu dan keadaan. Hal ini cenderung lebih mempertahankan bentukbentuk tata ruang yang telah disepakati bersama dengan menerima nilai-nilai baru tanpa menggugurkan tata nilai lama yang telah mentradisi (Ir. Nyoman Gelebet, Tradisional Bali, Hal. 20). Dalam konsep Hindu (Suandra, 1991), masyarakat Bali menerapkan nilai-nilai tradisional dalam penataan tata ruang bangunan tradisional Bali, antara lain: konsep Tri Hita Karana (menumbuhkan keselarasan hubungan antara lingkungan, manusia dan tuhan); konsepsi Tri Semaya (masa lalu, masa kini dan masa yang akan datang). Oleh sebab itu konsep Hindu dalam kehidupan sesungguhnya sangat menyadari perubahan, bahkan perubahan tersebut dipandang sebagai suatu Rta (hukum abadi alam semesta). Dari pandangan ini lahirlah konsep Desa Kala Patra yang memperhitungkan faktor ruang, waktu, dan keadaan. Ketiga konsep Hindu ini akan melahirkan konsep-konsep baru dalam tatanan pembangunan tradisional Bali dari hal makro sampai mikro. 
Pada ajaran agama Hindu sebagai dasar/pedoman pada kehidupan masyarakat Hindu di Bali, yang isinya secara garis besar mengandung nilai-nilai filosofis dalam memaknai tata ruang dalam suatu bangunan tradisional Bali yang terbagi menjadi tiga hal pokok yaitu: 1) Tatwa sebagai pengaturan pekarangan dan perwujudan tata bangunan, 2) Susila sebagai perwujudan norma-norma tata nilai dan tata letak dalam konsep keruangan, serata sistem kemasyarakatan, dan 3) Upakara, sebagai wujud bakti kepada Tuhan yang telah memberikan untuk membangun ruang dan tata letak bangunan.

Ketiga kerangka dasar diatas sangat mempengaruhi sikap hidup dan struktur kemasyarakatan, aktivitas, dan pengaturan lingkungan hidupnya, hal tersebut saling mempengaruhi yang digambarkan sebagai Manik Ring Cacupu (bayi dalam kandungan), membentuk konsep-konsep ruang secara runtut dari sekala makro (alam), lingkungan hunian. (desa), pekarangan rumah, bangunan, peralatan, sampai pada komponen-komponen terkecil (Widana, 2011).

Di dalam kehidupan bermasyarakat tentunya melakukan pelaksanaan dari upacara-upacara penghormatan selalu dilengkapi dengan sarana-sarana yang berupa upakara berbentuk sesajen sebagai pernyataan rasa bhakti terhadap sesama makhluk ciptaan. Pada arsitektur tradisional Bali hal ini terlihat jelas dalam proses pembangunan yang selalu disertai dengan deretan upacara, mulai dari proses, pencarian bahan (menebang kekayuan), penentuan lahan untuk bangunan (pekarangan) dengan upacara "nyukat karang" dan "mecaru” sebagai pernyataan permohonan untuk merubah fungsi site (lahan), upacara pembuatan standar ukuran (gegulak), upacara "ngeruak" sebagai pernyataan permohonan untuk mendirikan bangunan, upacara "memakuh" sebagai upacara perletakan batu pertama "nyejer daksina" sebagai permohonan keselamatan dan pengawasan kepada Begawan Wismakarma sebagai dewa para Arsitek tradisional Bali (undagi) agar selama proses pembangunan tidak ada gangguan dan kesalahan, upacara "pemelaspas" dan pengurip-urip sebagai pernyataan bersyukur atas terwujudnya bentuk baru, serta pengakuan dalam wujud tersebut memiliki kekuatan magis dan jiwa sebagaimana halnya manusia dan makhluk-makhluk lainnya. 
Namun pada umumnya, arsitektur tradisional Bali penuh dengan hiasan seperti ukiran, peralatan dan pemberian warna. ragam hias ini mengandung arti tertentu untuk mengungkapkan keindahan simbol-simbol serta penyampaian komunikasi. Ragam hias ini berupa berbagai jenis fauna yang ditampilkan dalam bentuk patung sebagai simbol-simbol dalam ritual. Arsitektur rumah Bali memang penuh dengan hiasan. Ukiran dan pahatan mengambil kehidupan di bumi berupa manusia, tumbuhan, dan juga binatang. Ragam ukiran atau hiasan yang ditempatkan pada sisi-sisi bangunan meliputi: 1) Keketusan, 2) Kekarangan, dan 3) Pepatran

Adapun nilai-nilai luhur budaya Bali yang memiliki harga dalam kehidupan masyarakat dan kebudayaan mencakup satu rentangan unsur-unsur abstrak (unsur budaya tak benda) yang terdiri dari: 1) Unsur Filosofis sebagai unsur yang paling dasar/abstrak, berisi hakekat dan kebenaran, 2) Unsur Nilai sebagai unsur tentang hal-hal yang berharga dalam kehidupan, 3) Unsur Konsep sebagai unsur instrumental/perdekatan ke tataran implementatif, dan 4) Unsur Norma dan Aturan sebagai unsur yang terkait dengan kehidupan nyata sehari-hari dan bernilai praksis.

Dalam nilai budaya Bali terdapat konsep Bhuana Agung (makro kosmos) dan Bhuana Alit (mikro kosmos), yang selalu dijaga keselarasan keduanya. Dari dua konsep inilah di turunkan menjadi suatu pendekatan dalam tata ruang yang kemudian memberikan pengertian adanya jiwa dalam penataan ruang di Bali yang dikenal dengan konsep Tri Hita Karana yang terdiri dari unsur jiwa, tenaga dan fisik atau nisa dikaitkan dengan Parahyangan, Pawongan dan Palemahan.

\section{PENUTUP}

Konsep rancang tata ruang pembangunan tradisional Bali yang memiliki unsur etik dalam teks lontar Asta Kosala-Kosali dan Asta Bhumi, sebagai pengungkapkan akan tata ruang pembangunan melalui tata letak, ukuran (sikut), posisi dan komposisi suatu bangunan. Hal ini juga tergantung beberapa bahan yang mendukung dalam merancang suatu ruang bangunan dimensi tradisional Bali. Konsep arsitektur Bali berkonsep pada Tri Hita Karana, Tri Angga, Tri Mandala, Dewata Nawa Sanga, Rwa Binedha, Tri Bhuwana dan Dinamika. 
Perkembangan tata ruang pembangunan tradisional Bali tetap berpedoman pada antropometri orang Bali sebagai pengguna bangunan, sehingga kesesuaian dan kenyamanan pengguna dapat dirasakan. Patokan tersebut sebagai acuan dimasyarakat Bali, bahwa tidak sembarangan orang untuk membangun suatu bangunan tanpa membaca sastra Lontar Asta Kosala-Kosali dan Asta Bhumi. Ini menjadi suatu pemahaman untuk mengenali lebih dalam mengenai tata ruang dan tata letak pembangunan tradisional Bali.

Tata ruang pembangunan tradisional Bali memiliki struktur dan fungsi yang sesuai dengan keadaan di Desa, Kala, Patra. Bahwa komposisi letak suatu bangunan sudah ditentukan dalam teks Lontar Asta Kosala-Kosali. Dalam aktivitas spiritual umat Hindu di Bali, tidak bisa terlepas yang namanya upacara, apalagi upacara membangun sebuah bangunan permanen tentunya menggunakan sarana dan prasarana pemujaan, agar terhindar dari mahabahaya dan selalu dilancarkan. Hal tersebut menjadikan sebuah makna dan filosofis tinggi mengenai kebenaran akan konsep pembangunan tradisional Bali.

\section{DAFTAR PUSTAKA}

Asta Bhumi, Alih Aksara Lontar, oleh Ida Nyoman Bodha (2007), Pusat Dokumentasi Kebudayaan Bali. Asal Lontar : Geria Jlantik Baler Margi Subagan.

Asta Kosala Kosali, Alih Aksara Lontar, oleh Ida Nyoman Bodha (2007), Pusat Dokumentasi Kebudayaan Bali. Asal Lontar : Geria Jlantik Baler Margi Subagan.

Ery Suardana, P. G. 2004. Pengukuran Antro- pometri Orang Bali Sesuai dengan Aspek Arsitektur Tradisional Bali, (Laporan penelitian), Universitas Dwijendra, Denpasar.

Gelebet, I Nyoman, Ir. 1958. Pokok-pokok Pengarahan Arsitektur Tradisional Bali

Gelebet I Nyoman, dkk. 1973. Arsitektur Tradisional Bali, Bali Information Centre, Bali. Parimin, Ardi P. 1986. Fundamental Study On Spatial Formation Of Island Village, Environmental Hierarchy Of Sacred-Profane Concept In Bali. Japan: Osaka University

Parwata, W. 2004. Dinamika Permukiman Perdesaan pada Masyarakat Bali, (Bahan Ajar), DIKTI, Jakarta.

Suandra, I M. 1991. Tuntunan dan Tata Cara Ngwangun Karang Paumahan Manut Smrti Agama Hindu, Proyek Pengadaan Prasarana dan Sarana Kehidupan Beragama di Bali, Denpasar.

Subawa, I Made Pasek. 2018. Nilai Teologis Arsitektur Tradisional Masyarakat Hindu Di Bali. Jurnal Genta Hredaya Volume 2 No.2, September 2018. 
Wibowo, Arif. 2009. Tata Ruang dalam Budaya Bali. Online (https:/ / staff.blog.ui.ac.id/arif51/2009/12/02/tata-ruang-dalam-budayabali/ diakses pada 20 Desember 2019)

Widana, Ida Bagus Gede. 2011. Dharmaning Hasta Kosali Arsitektur Tradisional Bali, Denpasar: Dharma Putra 